\title{
Propolis inhibited Bax expression and increased neuronal count of hippocampal area CA1 in rats receiving sodium nitrite
}

\author{
Kuswati*, Ety Sari Handayani*, Zainuri Sabta Nugraha*, Fishella Aprista Rahmanti**, \\ Zulfikar Loka Wicaksana**, and Muhammad Zhafirrahman**
}

ABSTRACT
BACKGROUND
Sodium nitrite induces hypoxia and oxidative stress in the hippocampus,
decreasing the number of neurons in the hippocampus and cognitive
function. Propolis contains chrysin that has antioxidant effects that are
expected to inhibit neuronal damage in the hippocampus. This study aims
to determine the effects of propolis on the expression Bcl-2-associated X
protein (Bax) and the number of neurons in the rat hippocampus receiving
sodium nitrite.

\section{METHODS}

This study of laboratory experimental design was conducted on 18 male Wistar strain rats (Rattus norvegicus), they were randomized into 3 groups: one control group $(\mathrm{K})$ received sodium nitrite and two intervention groups (P1 and $\mathrm{P} 2$ ) received sodium nitrite and propolis at doses of 100 and 200 $\mathrm{mg} / \mathrm{kgBW}$. Treatment with sodium nitrite and propolis were given for 60 days, followed by termination. The number of neurons and Bax expression in the hippocampal CA1 area were measured. One-way ANOVA was used to analyze the data.

\section{RESULTS}

There were significant differences in Bax expression between group $\mathrm{K}$ and groups P1 and P2 $(\mathrm{p}<0.001)$. The lowest number of neurons in the hippocampal CA1 area was in the $\mathrm{K}$ group. There were significant differences in the number of neurons between control (K) group and groups $\mathrm{P} 1$ and $\mathrm{P} 2(\mathrm{p}<0.001)$.

\section{CONCLUSION}

Propolis inhibited the expression of Bax and decreased the number of neurons in the hippocampal CA1 area of rats receiving sodium nitrite. This study provides information about the benefits of propolis as an antioxidant in the brain.

Keywords: Propolis, Bax, hippocampus, sodium nitrite
*Department of Anatomy,

Faculty of Medicine,

Universitas Islam Indonesia,

Yogyakarta

**Faculty of Medicine,

Universitas Islam Indonesia,

Yogyakarta

\section{Correspondence:}

dr. Kuswati, MSc

Department of Anatomy,

Faculty of Medicine,

Universitas Islam Indonesia

J1 Kaliurang km 14,5 Yogyakarta

Phone (0274) 898444

Email:kuswati@uii.ac.id

Date of first submission, December 17, 2018

Date of final revised submission, June 17, 2019

Date of acceptance, June 18, 2019

This open access article is distributed under a Creative Commons AttributionNon Commercial-Share Alike 4.0 International License

Cite this article as: Kuswati, Handayani ES, Nugraha ZS, et al. Propolis inhibited Bax expression and increased neuronal count of hippocampal area CA1 in rats receiving sodium nitrite. Univ Med 2019;38:73-80. doi: 10.18051/ UnivMed.2019.v38.73-80 


\section{INTRODUCTION}

Exposure to sodium nitrite results in structural and functional changes in various organs of the body. In the brain, the exposure results in congestion of the blood vessels and bleeding in the meninges, ventricles, brainstem and cerebellum. Exposure to sodium nitrite also results in perineuronal edema, vacuolation, neuronal degeneration, neurophagy and necrosis of the Purkinje cells in the cerebellum. ${ }^{(1)}$ The study conducted by Jebasingh et al. ${ }^{(2)}$ showed that intraperitoneal administration of sodium nitrite at a dose of $60 \mathrm{mg} / \mathrm{kgBW}$ in male Wistar rats for 30 days decreased the capacity for learning and memory and increased anxiety. In addition, administration of sodium nitrite resulted in changes in the morphology of the cortex, hippocampus, thalamus, and cerebellum. These changes are among others pyknotic nuclei and fragmented and vacuolated neurons resulting from apoptosis and neuronal degeneration.

Sodium nitrite is a compound that converts hemoglobin into methemoglobin, which causes hypoxia, thus leading to ischemia and inflammation of the brain. ${ }^{(3)}$ According to Halim and Ibrahim $^{(4)}$ the hypoxia increases reactive oxygen species (ROS), resulting in the degradation of lipid membranes and enzymes, and in DNA damage. Oxidative stress disturbs metabolic activity, inhibits expression of the factors of neuronal regeneration and proliferation in the hippocampus and decreases the number of receptors in the hippocampus. ${ }^{(5)}$ The hippocampus is one of the brain areas that are susceptible to oxidative stress. Exposure to stress in the hippocampus results in a decreased number of neurons in the hippocampus and amygdala and decreased memory and cognitive function. ${ }^{(6)}$

To protect the neurons in the hippocampus from hypoxia and oxidative stress as a result of exposure to sodium nitrite, a compound is needed, such as propolis, that possesses neuroprotective effects and prevents damage and death to the neurons. Propolis contains chrysin and has antioxidant and neuroprotective effects. Administration of propolis at a dose of $200 \mathrm{mg} /$ $\mathrm{kgBW}$ in rats exposed to stress and showing increases in $\mathrm{H}_{2} \mathrm{O}_{2}$ has the effect of decreasing the $\mathrm{H}_{2} \mathrm{O}_{2}$ concentration. ${ }^{(7)}$ Administration of propolis to rats with cerebral ischemia reduces apoptosis with increased expression of Bcl-2 and decreased expression of Bax and caspase-3. ${ }^{(8)}$ Propolis-containing polyphenols may prevent the death of dopaminergic neurons in the substantia nigra as a result of exposure to 6-OHDA (6hydroxydopamine), may increase the expression of brain-derived neurotrophic factor (BDNF), increase the antioxidant activity of enzymes such as superoxide dismutase (SOD), glutathione peroxidase (GPx), and glutathione reductase (GSR), and decrease the concentration of malondialdehyde that may cause oxidative stress in the neurons. ${ }^{(9)}$ In neuronal cell culture, administration of propolis at a dose of $25 \mu \mathrm{g} / \mathrm{mL}$ may prevent oxidative stress, inhibit release of LDH and increase the viability of the neurons as a result of exposure to $\mathrm{H}_{2} \mathrm{O}_{2} \cdot{ }^{(10)} \mathrm{In}$ rats with neurotoxicity induced by lead $(\mathrm{Pb})$ for four weeks, administration of propolis may inhibit the neurotoxic effect of $\mathrm{Pb}$. This is shown in the normal activity of acetylcholinesterase, decreased MDA concentrations in the brain, and increased activity of $\mathrm{NADH}$, succinate dehydrogenase (SDH) and cytochrome $\mathrm{C}$ oxidase in mitochondria. ${ }^{(11)}$ A previous study had evaluated the effect of propolis on the neuronal count in the hippocampus. ${ }^{(12)}$ Caffeic acid phenethyl ester (CAPE) is a phenolic chemical compound present in numerous plants and is extracted from honeybee hive propolis. ${ }^{(13)}$

The study of Wang et al. ${ }^{(14)}$ states that CAPE may inhibit the apoptosis of neurons as a result of sevoflurane exposure. This is shown by the decreased expression of the pro-apoptotic proteins $\mathrm{Bax}$ and $\mathrm{Bcl} 2$ associated agonist of cell death $(\mathrm{Bad})$ and the increased expression of the antiapoptotic proteins B cell CCL/lymphoma 2 $(\mathrm{Bcl} 2)$ and $\mathrm{Bcl} 2$ like 1 ( $\mathrm{Bcl} \mathrm{xL})$. CAPE inhibits neuronal apoptosis in the hippocampus that is marked by decreased numbers of terminal 
deoxynucleotidyl transferase dUTP nick end labeling (TUNEL) positive cells and decreased expression of activated caspase-3. ${ }^{(14)}$

In contrast with all of the above-mentioned studies, the present study aimed to evaluate the neuroprotective effect of propolis in inhibiting Bax expression and the decrease in hippocampal neuronal count of rats exposed to sodium nitrite.

\section{METHODS}

\section{Research design}

This was an experimental laboratory study of posttest only control group design, conducted at the Research Laboratory, Faculty of Medicine, Universitas Islam Indonesia (FK UII) from July to December 2017.

\section{Research subjects}

The subjects of this study were four-monthold male Wistar strain rats (Rattus norvegicus) weighing 200-300 grams. The required number of subjects were calculated from the formula of Charan and Biswas ${ }^{(15)}$ as follows:

$\mathrm{E}=$ Total number of animals - Total number of groups

$\mathrm{E}=10$ to 20

Total number of animals $=20$ - total number of groups

Total number of animals $=20-3$

From above calculation the required number of subjects was 17 rats. To obtain 6 subjects per group, the total number of subjects used was 18 rats. All experiments were performed according to the institutional guidelines of the Experimental Animal Center and in accordance with the principles outlined in the Guide for the Care and Use of Laboratory Animals.

\section{Preparation of propolis extract}

The propolis used in this study was a product available in the open market, in which 1 $\mathrm{ml}$ of the material contains $600 \mathrm{mg}$ propolis. From this propolis preparation $0.1 \mathrm{ml}$ was taken and $0.9 \mathrm{ml}$ distilled water was added, so as to obtain a concentration of $60 \mathrm{mg} / \mathrm{ml}$. The diluted propolis solution was then administered to the rats in the appropriate doses, i.e. $100 \mathrm{mg} / \mathrm{kgBW}$ and $200 \mathrm{mg} / \mathrm{kgBW}$, respectively, in accordance with the study by Lee et al. ${ }^{(16)}$

\section{Exposure to sodium nitrite and administration of propolis}

In the sodium nitrite only group (group K) sodium nitrite at a dose of $50 \mathrm{mg} / \mathrm{kgBW} /$ day was administered orally for 60 days by means of a gastric tube. In the group receiving sodium nitrite and propolis (groups $\mathrm{P} 1$ and $\mathrm{P} 2$ ), sodium nitrite at a dose of $50 \mathrm{mg} / \mathrm{kgBW} /$ day and propolis at doses of 100 and $200 \mathrm{mg} / \mathrm{kgBW} /$ day, respectively, were administered by the oral route for 60 days by means of a gastric tube.

\section{Sample preparation}

On day 61 , when the rats were terminated and underwent transcardial perfusion, the rats were anesthesized by intramuscular injection of ketamine $(100 \mathrm{mg} / \mathrm{kg})$. The transcardial perfusion was done with a solution of $\mathrm{NaCl}$ at a volume of 100-200 ml until the emerging perfusion fluid was clear. After perfusion, the brain was carefully excised, the part containing the hippocampus was taken and fixed in phosphatebuffered formalin for 24 hours. It was subsequently made into paraffin blocks and sectioned at $3 \mu \mathrm{m}$ thickness. From each rat brain one slice was taken for immunohistochemical staining and one slice for hematoxylin-eosin staining.

Immunohistochemical staining was initiated by deparaffinizing with xylol and alcohol in decreasing concentrations. The tissue was then incubated with $3 \% \mathrm{H}_{2} \mathrm{O}_{2}$ in $10 \%$ methanol for 20 minutes and washed three times with distilled water followed with three times phosphatebuffered solution (PBS). Subsequently antigen retrieval was carried out in citrate buffer at $\mathrm{pH}$ 6 in a microwave oven. For about 10 minutes, the slices were heated to a high temperature $\left(100^{\circ} \mathrm{C}\right)$, followed by med-low temperature for 20 minutes. After cooling, the slices were again 
washed three times with PBS. Subsequently the slices were blocked with background sniper for 10 minutes. Without washing again, the tissue was dripped with Bax primary antibody $(\mathrm{Ab})$ and incubated overnight at $4{ }^{\circ} \mathrm{C}$, then washed three times in PBS and incubated with Trekkie Universal Link for 10 minutes. After washing three times with PBS, the tissue was incubated with horseradish peroxidase-conjugated streptavidin (SA-HRP complex) for 10 minutes, then washed again three times with PBS. Baxlabeled pyramidal cells were visualized with $3,3^{\prime}$ diaminobenzidine (DAB) $(1: 100)$ for 5 minutes. The tissue was then washed five times with distilled water, followed by counterstaining with Mayer's hematoxylin for one minute. After washing in running water for 2 minutes, the slices were dehydrated in ethanol $70 \%, 80 \%, 90 \%$, $95 \%$ and $100 \%$, for one minute, respectively, cleared in xylol and covered with Canada balsam and coverslip.

Hematoxylin-eosin staining was performed according to the protocol of the Research Laboratory of the Faculty of Medicine, UII. Briefly, the protocol was as follows: The slides with the tissue sections were placed in the staining jar, deparaffinized, then washed twice with distilled water. Then the slides were placed in hematoxylin solution for 10 minutes, washed three times with distilled water, and checked under the microscope. If the hematoxylin staining was adequate, the slides were washed in running water. Subsequently the slides were placed in eosin and washed twice with distilled water. The slides were then placed in $70 \%, 80 \%, 90 \%, 95 \%$ and $100 \%$ alcohol, and dried with tissue paper. The dried slides were placed in xylol I, II and III for 5 minutes, respectively, followed by mounting and were then observed under the microscope.

\section{Observation of Bax-expressing cells}

Observation of Bax-expressing cells was performed in the hippocampal area CA1. The slide preparations were observed under the light microscope at $400 \mathrm{x}$ magnification. The whole hippocampal area CA1 was observed and the Bax expression interpreted using the Allred score, which evaluates the proportions and staining intensities of cells with positive Bax expression.

The Allred score is semi-quantitative, using the proportion of positive cells (scores 0-5) and staining intensity (scores $0-3$ ), which are summed to yield the total score $(0-8) .^{(17)}$

As per the Allred score for Bax-expression, the proportion score (PS) and the \% positive tumor cells are respectively, $(-)(0 \%),(+)(<1 \%)$, $(++)(1-10 \%),(+++)(11-33 \%),(++++)(34-$ $66 \%)$, and $+++++(67-100 \%)$. The intensity of staining (IS) for the nuclear positivity of the cells graded as $0,1,2$, and 3 was as negative, weak, mild, intermediate, and strong, respectively. Allred score is obtained by adding up the proportion score and intensity score.

\section{Hippocampal neuronal count}

The neuronal count was performed in area CA1 of the hippocampus. The slides were observed under the light microscope at $400 \mathrm{x}$ magnification. The cells were counted in the whole hippocampal area CA1. Then the mean number of neurons per field of view for each slide was calculated with the formula: mean number of cells $=$ number of cells in area under observation/number of fields of view.

\section{Data analysis}

To compare the mean Allred score for Bax expression and aeuronal count between groups in the hippocampus, one-way Anova was used, followed by Tukey's multiple comparison post hoc test to determine the differing groups. A $p$ value of less than 0.5 shows a significant difference.

\section{Ethical clearance}

This study obtained ethical clearance from the Committee on Research Ethics, Faculty of Medicine, Universitas Islam Indonesia, under no. 03/Ka.Kom.Et/70/KE/VII/2017. 
Table 1. Mean Bax expression and pyramidal neuronal count in the hippocampus

\begin{tabular}{lcccc}
\hline & \multicolumn{3}{c}{ Intervention } & p value \\
\cline { 2 - 4 } & K & P1 & P2 & \\
\hline Bax expression & $7.27 \pm 0.43$ & $4.07 \pm 0.65$ & $4.06 \pm 0.72$ & 0.000 \\
Pyramidal neuronal count & $26.0 \pm 2.53$ & $46.0 \pm 4.27$ & $49.0 \pm 3.05$ & 0.000 \\
\hline
\end{tabular}

$\mathrm{K}$ : sodium nitrite; P1: sodium nitrite + propolis at $100 \mathrm{mg} / \mathrm{kgBW}$; 2 : sodium nitrite + propolis at $200 \mathrm{mg} / \mathrm{kgBW}$

\section{RESULTS}

The results of the evaluation of Bax expression in area CA1 of the hippocampus using the Allred score are presented in Table 1. Group $\mathrm{K}$ receiving treatment with sodium nitrite had the highest mean Allred score. Analysis using one-way ANOVA showed significant results $(p=0.000)$. Post-hoc analysis demonstrated significant differences between group $\mathrm{K}$ and groups $\mathrm{P} 1$ and $\mathrm{P} 2$. There was no significant difference between groups $\mathrm{P} 1$ and P2 (Table 2).

The results of the pyramidal neuronal count in hippocampal area CA1 of the control group $(\mathrm{K})$, treatment group $1(\mathrm{P} 1)$, and treatment group 2 (P2) are presented in Table 1. Analysis with one-way ANOVA showed significant results ( $\mathrm{p}=$ 0.000 ). The post-hoc analysis also showed significant differences between group $\mathrm{K}$ and groups $\mathrm{P} 1$ and $\mathrm{P} 2$. However, there were no significant differences between group $\mathrm{P} 1$ and group P2 (Table 2).

\section{DISCUSSION}

In this study, exposure to sodium nitrite increased Bax expression in area CA1 of the hippocampus, which agrees with the study of Zaidi ${ }^{(18)}$ stating that exposure to sodium nitrite causes degeneration in the hippocampus in areas CA1CA4 and the gyrus dentatus, showing the presence of pyknotic nuclei, darkly stained cells, cells with condensed nuclei, and vacuolation. The neuronal count in the hippocampus also underwent a decrease as a result of the exposure to sodium nitrite. In another study Zaidi ${ }^{(19)}$ found that sodium nitrite causes damage to the Purkinje cells in the cerebellum. Morphological changes in the Purkinje cells comprised swollen, autolyzed dark and shrunken nuclei. This shows that Purkinje cells of the cerebellum are susceptible to the hypoxia that results from the exposure to sodium nitrite so that the cells degenerate. Amin et al. ${ }^{(1)}$ report that exposure to sodium nitrite decreases the number of red blood cells and the hemoglobin concentration. Hypoxia may cause leakage of the mitochondrial membrane so that cytochrome-C will enter the cytosol and activate pro-apoptotic proteins followed by apoptosis of the cell. ${ }^{(20)}$

In the present study the pyramidal neuronal count in area CA1 of the hippocampus underwent a greater reduction in group $\mathrm{K}$ as compared with groups $\mathrm{P} 1$ and $\mathrm{P} 2$. This result is similar to that of the study by Amin et al..$^{(1)}$ who found congestion of blood vessels and bleeding in meninges, cerebrum and cerebellum. In addition, apparently the Purkinje cells of the cerebellum undergo degeneration and necrosis. Exposure to sodium nitrite in the brain results in neurotoxicity that is marked by an increase in serum biochemical parameters, such as nitrates, thiobarbituric acidreactive substances (TBARS) and a decrease in glutathione and dopamine concentrations. ${ }^{(21)}$ The study conducted by Jebasingh et al. ${ }^{(2)}$ shows that intraperitoneal administration of sodium nitrite at $60 \mathrm{mg} / \mathrm{kgBW}$ in male Wistar rats for 30 days

Table 2. Results of Tukey's multiple comparison test

\begin{tabular}{|c|c|c|}
\hline & $\begin{array}{c}\text { Mean } \\
\text { difference }\end{array}$ & p value \\
\hline \multicolumn{3}{|c|}{ Bax expression } \\
\hline \multirow{2}{*}{$\mathrm{K}$} & 3.20 & 0.001 \\
\hline & 3.21 & 0.000 \\
\hline $\mathrm{P} 1 \quad \mathrm{P} 2$ & 0.01 & 0.989 \\
\hline \multicolumn{3}{|c|}{ Pyramidal neuronal count } \\
\hline \multirow{2}{*}{$\begin{array}{ll}\mathrm{K} & \mathrm{F} \\
& \mathrm{F}\end{array}$} & 20 & 0.000 \\
\hline & 23 & 0.000 \\
\hline $\mathrm{P} 1 \quad \mathrm{P} 2$ & 3 & 0.309 \\
\hline
\end{tabular}

$\mathrm{K}$ : sodium nitrite; P1: sodium nitrite + propolis at $100 \mathrm{mg} /$ $\mathrm{kgBW}$; P2: sodium nitrite + propolis at $200 \mathrm{mg} / \mathrm{kgBW}$ 
decreases learning ability and memory and increases the anxiety level in tests with the elevated plus maze. In addition, induction of hypoxia with subcutaneous administration of sodium nitrite at a dose of $50 \mathrm{mg} / \mathrm{kgBW}$ decreases locomotor activity and motor coordination in male Wistar rats. ${ }^{(22)}$

According to Jebasingh et al., ${ }^{(2)}$ morphological examination of the cortex, hippocampus, thalamus, and cerebellum shows changes resulting from exposure to sodium nitrite. The changes comprise pyknotic and rounded nuclei, with fragmented dead neurons and vacuolation. The afore-mentioned brain areas play an important role in the regulation and coordination of movement and behavior. The morphological changes are caused by apoptosis and neuronal degeneration. Mohammed (23) reports that administration of sodium nitrite at a dose of $30 \mathrm{mg} / \mathrm{kgBW}$ causes histopathological damage in various brain areas, including area CA1 of the hippocampus that is marked by loss of pyramidal cells and increase in vascular endothelial growth factor (VEGF).

The results of the present study show that administration of propolis at doses of 100 and 200 $\mathrm{mg} / \mathrm{kgBW}$ may inhibit the decrease in pyramidal neuronal count in area $\mathrm{CA} 1$ of the hippocampus. This condition is consistent with previous studies showing that propolis inhibits the decrease in neuronal count in area CA1 of the hippocampus and the cortex prefrontalis in rats with induced stress. ${ }^{(12)}$ Propolis may inhibit oxidative stress with increased activity of antioxidant enzymes in rats that were induced with 6-hydroxydopamin to trigger Parkinson's disease. ${ }^{(9)}$ Propolis contains caffeic acid phenyl ester (CAPE) as antioxidant, that may inhibit neurotoxicity and neuronal degeneration in the cerebrum and cerebellum as a result of exposure to ethanol. ${ }^{(24)}$

In this study, administration of propolis in groups $\mathrm{P} 1$ and $\mathrm{P} 2$ decreased Bax expression in area CA1 of the hippocampus. The results of this study are in agreement with the study by Basarslan et al. ${ }^{(24)}$ who reported that administration of CAPE may inhibit the apoptosis of neurons in the cerebrum and cerebellum. In rats receiving ethanol and CAPE, expression of Bax and caspase-3 was lower than in rats exposed to ethanol only. Expression of Bcl-2 was higher in rats exposed to ethanol and then given CAPE. Propolis contains flavonoids with strong antioxidant and anti-inflammatory effects. Administration of propolis at doses of 100 and 200 $\mathrm{mg} / \mathrm{kgBW}$ decreases apoptosis in rat brain tissue examined by TUNEL immunohistochemistry, decreases expression of TNF- $\alpha$ in brain tissues of a rat model of traumatic brain injury (TBI) and decreases the area of necrosis. ${ }^{(25)}$ Annis et al. ${ }^{(26)}$ report that administration of propolis at doses of 50,100 and $200 \mathrm{mg} / \mathrm{kgBW}$ for 7 days may decrease apoptosis and increase expression of BDNF in the brain of a Rattus norvegicus traumatic model. Decrease in apoptosis and increase in BDNF expression is proportional to dose increases. The most effective dose of propolis is $200 \mathrm{mg} / \mathrm{kgBW} /$ day. The dose of 50 $\mathrm{mg} / \mathrm{kgBW}$ is less effective in increasing BDNF expression. The study of Khalil et al. ${ }^{(27)}$ shows that propolis may reduce the toxic effect of methotrexate in the liver and brain. Propolis increases the glutathione (GSH) concentration, increases the antioxidant activity of superoxide dismutase (SOD), glutathione peroxidase (GPx), and glutathione reductase (GSR) in the liver and brain tissues and decreases the malondialdehyde (MDA) concentration. Propolis is capable of modulating enzyme antioxidant activity and reduce the oxidative damage caused by methotrexate. Administration of propolis in a rat model of spinal cord injury was able to decrease the concentrations of caspase 3 and cathepsin B. ${ }^{(28)}$

The results of the present study differ from those of the study by Hemieda et al. ${ }^{(29)}$ who tested the effect of the administration of propolis in a rat model of diabetes. Diabetic rats were given propolis orally in two separate doses, 50 or $100 \mathrm{mg} / \mathrm{kg} \mathrm{BW} /$ day for 6 weeks. The obtained results show that administration of propolis induced apoptosis and cell cycle arrest in the pancreas of diabetic rats, that are marked by 
increased $\mathrm{p} 53$ and caspase- 3 in the $\mathrm{G} 0 / \mathrm{G} 1$ phases; and decreased $\mathrm{Bcl}-2$, as compared with the untreated diabetic rats. In spite of this, the administration of propolis markedly reduced oxidative stress, as seen in the decreased concentrations of malondialdehyde (MDA) and carbonyl proteins in the liver and pancreas. Administration of propolis increased the capacity of the antioxidant defense system by increasing the content of glutathione (GSH), superoxide dismutase (SOD), catalase (CAT) and total antioxidants (TAC) in the liver and pancreas. Administration of propolis significantly improved inflammation as shown in the decrease in serum markers of inflammation such as C-reactive protein (CRP), interleukin 10 (IL-10) and transforming growth factor $\beta$ (TGF- $\beta$ ), in comparison with untreated diabetic rats.

One of the clinical implications of the results of this study is the use of propolis to inhibit the neurodegeneration resulting from exposure to sodium nitrite. One of the limitations of this study is that only one piece of the brain was taken as the sample. Further studies should take a larger number of samples using stereology. This study only determined the expression of Bax as one of proapoptotic proteins. Further studies may be performed by determining all markers of apoptosis, such as caspases (caspase 3, 8 and 9), Bad, Bcl 2 and Bcl-XL and count the number of cells undergoing apoptosis with the TUNEL assay.

\section{CONCLUSION}

Administration of propolis is capable of inhibiting Bax expression and the decrease in neuronal count in area CA1 of the hippocampus in rats receiving sodium nitrite. This study provides information on the benefits of propolis as a brain antioxidant.

\section{CONFLICT OF INTEREST}

There was no conflict of interest in this study.

\section{ACKNOWLEDGMENT}

The authors thank the Research and Community Service Unit, Faculty of Medicine, Universitas Islam Indonesia, for the funding of the study through the lecturer grant schema (skema hibah dosen)..

\section{CONTRIBUTORS}

$\mathrm{K}$ designed the study, wrote the protocol and the first draft of the manuscript. ZSN revised the manuscript. ESH revised the protocol and manuscript. FAR, ZLW, MZ carried out the study. All authors have read and approved the final manuscript.

\section{REFERENCES}

1. Amin RA, Elsabagh RA, Amin A. Protective effects of ascorbic acid and garlic oil against toxic effects induced by sodium nitrite as meat additive in male rats. Global Veterinaria 2016;16:508-24. doi: 10.5829/idosi.gv.2016.16.06.10393.

2. Jebasingh D, Jackson DD, Venkataraman S, et al. The protective effects of Cyperus rotundus on behavior and cognitive function in a rat model of hypoxia injury. Pharm Biol 2014;52:1558-69. doi: 10.3109/13880209.2014.908395.

3. McGinnis WR, Audhya T, Edelson SM. Proposed toxic and hypoxic impairment of a brainstem locus in autism. Int $\mathrm{J}$ Environ Res Public Health 2013;10:6955-7000. doi: 10.3390/ijerph10126955.

4. Halim HDP, Ibrahim N. Efek neuroprotektif ekstrak akar Acalypha indica $500 \mathrm{mg} / \mathrm{kgBB}$ terhadap perubahan inti sel saraf hipokampus pascahipoksia serebri. eJKI 2013;1:113-7. https:// doi/org/10.23886/ejki.1.2057.113-117.

5. Sunarno, Manalu W, Nastiti, et al. Pengoptimalan kinerja motorik pada penuaan fisiologis dan penuaan akibat stres oksidatif dengan alaninglutamin dipeptida dan hubungannya dengan perbaikan fungsi hippocampus. J Kedokteran Hewan 2012;6:56-9. doi: https://doi.org/10.21157/ j.ked.hewan.v6i1.354.

6. Fitranto A, Soejono SK, Maurits LS, et al. Jumlah sel piramidal CA3 hippocampus tikus putih jantan pada berbagai model stres kerja kronik. MKB 2014;46:197-202. doi: 10.15395/mkb.v46n4.337.

7. Seven PT., Yilmaz S, Seven I, et al. The effect of propolis in animals exposed oxidative stress. In: Oxydative stress - environmental induction and 
dietary antioxidants. Lushchak V, editor. Rijeka, Croatia: InTech Europe;2012.pp.267-88. doi: $10.5772 / 34850$.

8. Fei YQ, Dong BD. Effect of propolis flavonoids on the apoptosis of neuron and expression of caspase-3, bcl-2 and bax following focal cerebral ischemia reperfusion in rats. Chinese $\mathrm{J}$ Clin 2010;4:1023-27.

9. Safari M, Sameni HR, Badban L, et al. Protective effect of water extracy of propolis on dopaminergic neurons, brain derived neurotrophic factor and stress oxidative factors in the rat model of Parkinson's disease. Int J Pharmacol 2015;11:300-08. doi: 10.3923/ijp.2015. 300.308 .

10. Jeong CH, Jeong HR, Kim DO, et al. Phenolics of propolis and in vitro protective effects against oxidative stress induced cytotoxicity. J Agric Life Sci2012; 46:87-95.

11. El-Masry TA, Emara AM, Shitany NA. Possible protective effect of propolis against lead induced neurotoxicity in animal model. J Evol Biol Res 2011;3:4-11.

12. Kuswati, Handayani ES, Nugraha ZS. Propolis increases neuronal count in hippocampal area CA1 and prefrontal cortex in stressed rats. Univ Med 2017;36:214-20. doi: 10.18051/UnivMed.2017. v36.214-220.

13. Demestre M, Messerli SM, Celli N, et al. CAPE (caffeic acid phenethyl ester)-based propolis extract (Bio 30) suppresses the growth of human neurofibromatosis (NF) tumor xenografts in mice. Phytother Res 2009;23:226-30. doi: 10.1002/ ptr.2594.

14. Wang LY, Tang ZJ, Han YZ. Neuroprotective effects of caffeic acid phenethyl ester against sevoflurane induced neuronal degeneration in the hippocampus of neonatal rats involve MAPK and PI3K/Akt signaling pathways. Mol Med Rep 2016;14:3403-12. doi: 10.3892/mmr.2016.5586.

15. Charan J, Biswas T. How to calculate sample size for different study designs in medical research? Indian J Psychol Med 2013;35:121-6. doi: 10.4103/ 0253-7176.116232.

16. Lee MS, Kim YH, Park WS. Novel antidepressantlike activity of propolis extract mediated by enhanced glucocorticoid receptor function in the hippocampus. Evidence-Based Complementary Alternative Medicine 2013, Article ID 646039, 10 pages. doi: http://dx.doi.org/10.1155/2013/217853.

17. Allred DC, Harvey JM, Berardo M, et al. Prognostic and predictive factors in breast cancer by immunohistochemical analysis. Mod Pathol 1998;11:155-68.
18. Zaidi ZF. Sodium nitrite-induced hypoxic injury in rat hippocampus. Pak J Med Sci 2010;26:532-7.

19. Zaidi ZF. Effects of sodium nitrite-induced hypoxia on cerebellar Purkinje cells in adult rats: Pak J Med Sci 2010;26:261-6.

20. Hidayat A, Wiradisastra K, Hernowo BS, et al. Ekspresi Bcl-2 dan Caspase-3 pascapaparan hipoksia hipobarik intermiten. MKB 2011;43:16670. doi: http://dx.doi.org/10.15395/mkb.v43n4.64

21. Rao VP, Kumar ACK, Kumar JV, et al. Evaluation of neuroprotective activity of Aegle marmelos (fruit) against sodium nitrite induced neurotoxicity in Albino Wistar rats. Int $\mathrm{J}$ Innovative Pharmac Res 2014;5:374-7.

22. Dimitrova D, Getova D. Effect of cholinesterase inhibitors tacrine and metrifonate on exploratory activity in rats with induced hypoxia. Sci Technol 2015;5:400-4.

23. Mohammed FF. Comparative neuropathological study of sodium nitrite and nisin exposed rats with special reference to expression of glial fibrillar acidic protein and vascular endothelial growth factor. Egypt J Comp Path Clinic Path 2013;26:6171.

24. Basarslan SK, Osun A, Senol S, et al. Protective effects of intralipid and caffeic acid phenyl esther (CAPE) on neurotoxicity induced by ethanol in rats. Turk Neurosurg 2017;27:66-73. doi: 10.5137/ 1019-5149.JTN.14463-15.2.

25. Chandra A, Ali M, Purnomo H. Efek ekstrak propolis terhadap ekspresi TNF- $\alpha$, apoptosis dan nekrosis jaringan otak tikus model traumatic brain injury (TBI). J Kedokter Brawijaya 2016;29:11724.

26. Annis F, Purnomo H, BalafifF. Pengaruh ekstrak propolis terhadap apoptosis melalui ekspresi brain-derived neurotrophic factor (BDNF) pada sel otak tikus model cedera otak traumatic. J Kedokter Brawijaya 2017;29:209-15.doi: http:// dx.doi.org/10.21776/ub.jkb.2017.029.03.5.

27. Khalil FA, El-Kirsh AAA, Kamel EA, et al. Beneficial effect of propolis extract (bee glue) against methotrexate induced stress in liver and brain of albino rats. Indian J Med Res Pharmac Sci 2016;3:24-34. doi: 10.5281/zenodo.54549.

28. Ozkara E, Durmaz R, Kanbak G, et al. The effect of propolis following experimental spinal cord injury. WScJ 2014;5:6-11.

29. Hemieda FAE, El-Kholy WM, Al-Habibi ESM, et al. Influence of propolis on oxidative stress, inflammation and apoptosis in streptozotocininduced diabetic rats. Int J Adv Res 2015;3:83145. 